\title{
ULTRASTRUCTURE OF THE TEGUMENT OF Metamicrocotyla macracantha (ALEXANDER, 1954) KORATHA, 1955 (MONOGENEA, MICROCOTYLIDAE)
}

\author{
COHEN, S. C., KOHN, A.* and BAPTISTA-FARIAS, M. F. D. \\ Laboratório de Helmintos Parasitos de Peixes, Departamento de Helmintologia, Instituto Oswaldo Cruz, FIOCRUZ, \\ Av. Brasil, 4365, CEP 21045-900, Rio de Janeiro, RJ, Brazil. *CNPq. \\ Correspondence to: Simone C. Cohen, Laboratório de Helmintos Parasitos de Peixes, \\ Departamento de Helmintologia, Instituto Oswaldo Cruz, FIOCRUZ, Av. Brasil, 4365, \\ CEP 21045-900, Rio de Janeiro, RJ, Brazil, e-mail: scohen@ioc.fiocruz.br \\ Received April 5, 2002 - Accepted January 21, 2003 - Distributed February 29, 2004
}

(With 5 figures)

\begin{abstract}
The ultrastructure of the body tegument of Metamicrocotyla macracantha (Alexander, 1954) Koratha, 1955, parasite of Mugil liza from Brazil, was studied by transmission electron microscopy. The body tegument is composed of an external syncytial layer, musculature, and an inner layer containing tegumental cells. The syncytium consists of a matrix containing three types of body inclusions and mitochondria. The musculature is constituted of several layers of longitudinal and circular muscle fibers. The tegumental cells present a well-developed nucleus, cytoplasm filled with ribosomes, rough endoplasmatic reticulum and mitochondria, and characteristic organelles of tegumental cells.
\end{abstract}

Key words: ultrastructure, tegument, Metamicrocotyla macracantha, Monogenea.

\section{RESUMO}

Ultra-estrutura do tegumento de Metamicrocotyla macracantha (Alexandre, 1954) Koratha, 1955 (Monogenea, Microcotylidae)

Foi realizado o estudo do tegumento do corpo de Metamicrocotyla macracantha (Alexander, 1954) Koratha, 1955, parasito de Mugil liza (tainha) do Canal de Marapendi, Rio de Janeiro, Brasil, pela microscopia eletrônica de transmissão. $\mathrm{O}$ tegumento é formado por uma camada externa sincicial, uma camada muscular e uma camada interna contendo células tegumentares. $\mathrm{O}$ sincício consiste em matriz com três tipos de corpos de inclusão e mitocôndrias. A musculatura é formada por diversas camadas de fibras musculares longitudinais e circulares. As células tegumentares apresentam núcleo bem desenvolvido, citoplasma preenchido por ribossomas, retículo endoplasmático rugoso e mitocôndrias, organelas características das células tegumentares.

Palavras-chave: ultra-estrutura, tegumento, Metamicrocotyla macracantha, Mongenea.

\section{INTRODUCTION}

The body tegument has been studied by transmission electron microscopy in only a few species of the Microcotylidae: Atriaster sp. by Justine (1992), Microcotyle sp. by Justine \& Bonami (1993), Atriaster heterodus by Santos \& Lanfredi (2000), and in Paranaella luquei by Cohen et al. (2001).
Metamicrocotyla macracantha (Alexander, 1954) has been reported from marine fishes belonging to the genus Mugil at several places worldwide (Koratha, 1955; Hargis, 1956; Bravo-Hollis, 1966, 1982; Young, 1970; Tantaleán, 1974; Skinner, 1975, 1978; Rawson, 1976; Minchew, 1977; Collins, 1985; Conroy et al., 1985, 1986; Garcia \& Williams, 1985; Oliva \& Munoz, 1985; Bargiela, 1987; Juarez-Arroyo 
\& Salgado-Maldonado, 1989; Kohn et al., 1994; Luque, 1994; Knoff et al., 1997).

The surface topography of $M$. macracantha was described through scanning electron microscopy by Kohn et al. (1994), with their transmission electron microscopic observations related to those for spermiogenesis and spermatozoa as reported by Baptista-Farias et al. (1995) and vitelline cells by Baptista-Farias \& Kohn (1998).

The present study describes the tegument ultrastructure of M. macracantha, a parasite from Mugil liza from Rio de Janeiro.

\section{MATERIALS AND METHODS}

Specimens of Metamicrocotyla macracantha were collected from the gills of Mugil liza (Val.) (Mugilidae) obtained from fishermen of Canal de Marapendi, Barra da Tijuca, Rio de Janeiro, Brasil. The helminths were fixed in $0.1 \mathrm{M}$ phosphate-buffer $2.5 \%$ glutaraldehyde, post-fixed for $1 \mathrm{~h}$ in $1 \%$ osmium tetroxide in the same buffer, dehydrated in an increasing graded ethanol series, and embedded in Epon (Luft, 1961). Ultrathin sections obtained using a Reichert Ultracut E-microtome were collected in 200 mesh grids, contrasted with uranyl acetate for $30 \mathrm{~min}$ and Reynold's solution of lead citrate for $5 \mathrm{~min}$, and observed under a Zeiss EM electron microscope.

\section{RESULTS}

The body tegument of Metamicrocotyla macracantha is composed of an external syncytial layer and musculature, and an inner layer containing tegumental cells (Fig. 1). The external syncytial layer is delimited by the apical and basal plasma membranes (Figs. 2 and 4, respectively). The apical plasma membrane is coated by the glycocalyx which presents ridges at regular intervals. A fibrous terminal web is observed immediately beneath the apical plasma membrane (Fig. 2).

The basal plasma membrane presents thin projections which extend into the syncytial layer continuous with the basal lamina, which is just beneath and presents uniform, thickness, without folds (Fig. 4).

The syncytium consists of a matrix containing three different types of body inclusions: round bodies (Fig. 2, n. 1); electrondense bodies (Fig. 2, n. 2); and electronlucent vesicles (Fig. 2, n. 3), which in some regions of the syncytium seem to be fused, forming a multivesicular body. The density of these body inclusions varies, according to the region of the tegument. In some regions, the electronlucent vesicles are more abundant (Fig. 2) while, in others, the electrondense bodies predominate (Fig. 3). Round to elongate mitochondria presenting about six cristae and sparse distribution (Figs. 2 and 4) were also observed.

The musculature is constituted by several layers of longitudinal and circular muscle fibers, presenting large and round to elongate associated mitochondria, which are surrounded by a limiting membrane, and present one to six well-defined cristae (Fig. 5). The space between the muscle fibers and mitochondria is filled with interstitial material, and neuromuscular plates are observed in the muscle fiber extremities (Fig. 5).

The irregularly shaped tegumental cells present nuclei without defined regions of heterochromatin, cytoplasm filled with ribosomes, rough endoplasmatic reticulum, and mitochondria with many cristae (Fig. 1).

\section{DISCUSSION}

The body tegument of Metamicrocotyla macracantha follows the general pattern described in monogenean species already studied, although presenting a few differences.

Microvillous-like tegumental projections have been observed in the tegument of some microcotylid species, as in Atriaster sp. by Justine (1992), Atriaster heterodus by Santos \& Lanfredi (2000), and Paranaella luquei by Cohen et al. (2001). They had not been observed in the present species, as in Microcotyle sp. by Justine \& Bonami (1993).

Metamicrocotyla macracantha was found coiled in the branchial filaments, as referred to by Minchew (1977) and Conroy et al. (1985, 1986). This characteristic position could explain the absence of microvillous-like tegumental projections in the body tegument, since these structures could be prejudicial to the host tissue. According to Halton (1979), the absence of microvillous proportions better contact between host and parasite.

The differences in the morphology and in the electrondensity of body inclusions found in the tegument suggest that they probably have different biochemical properties and functions (Ramasamy \& Bhuvaneswari, 1993). Similar inclusions presenting variations in pattern and distribution were reported on the tegument of many Monogenea (Halton, 1982; Smyth \& Halton, 1983; Threadgold, 1984). 

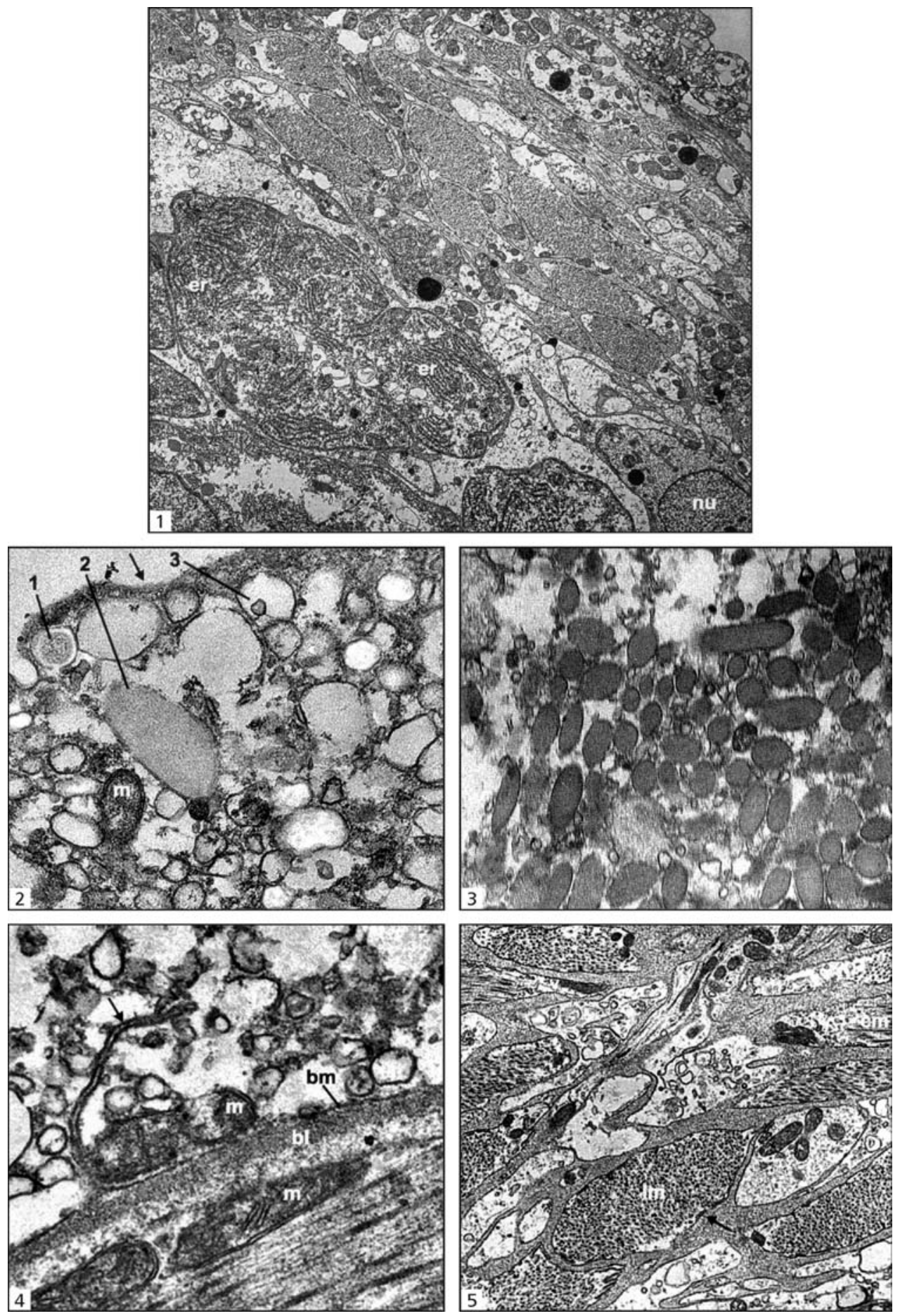

Figs. 1-5 - Transmission electron micrographs of the tegument of Metamicrocotyla macracantha. Fig. 1 - Transversal section of body showing the general view of the tegument, composed by an external syncytial layer, musculature and tegumental cells with nucleus (nu) and endoplasmatic reticulum (er). The 5,000 x. Fig. 2 - Apical region of the tegument showing the external syncytial layer presenting a terminal web (arrow), three types of body inclusions: round bodies (n. 1), electrondense bodies (n. 2), and electronlucent vesicles (n. 3) and mitochondria (m). The 40,000 x. Fig. 3 - Detail of the external syncytial layer showing a region where the electrondense bodies are more abundant. The 19,000 x. Fig. $4-$ High magnification of the basal region of the external syncytial layer showing the thin projections (arrow) of the basal plasma membrane (bm), mitochondria (m), and basal lamina (bl). The 50,000 x. Fig. 5 - Musculature of body constituted by circular and longitudinal fibers ( $1 \mathrm{~m}$ ), associated mitochondria, and detail of neuromuscular plates (arrow), 10,000 x 
The basal invaginations observed in the external syncytial layer suggest that the tegument has a hole for obtaining nutrients, for excretion, and for osmorregulation (Brennan \& Ramasamy, 1996). According to Lyons (1972), thin projections of this membrane, as observed in M. macracantha, are filled by a reticulin-like substance forming the cytoskeleton and are related to the sustenance of the tegumental external layer.

The body musculature of $M$. macracantha is well developed. The folds observed are due to contraction of longitudinal and circular muscle fibers. Neuromuscular plates were observed in the extremity of the fibers, as in the musculature of Pricea multae (Ramasamy et al., 1986). Mitochondria of the muscular layer are smaller than those found in the external syncytium, as in other Polyopisthocotylea such as Vallisia indica (Ramasamy et al., 1987), although in $P$. luquei (Cohen et al., 2001) the mitochondria of the external layer are smaller.

The fibrous terminal web, observed just beneath the apical plasma membrane, was also observed in other Microcotylidae, as Microcotyle sp. by Justine \& Bonami (1993) and in Atriaster sp. by Justine (1992) and P. luquei (Cohen et al., 2001). According to Lyons (1973), this web is a feature displayed by Polyopisthocotylea and had not been observed in Monopisthocotylea.

The synthesis of tegumental inclusions involves the rough endoplasmatic reticulum and Golgi complex, characteristic organelles of tegumental cells. In the tegument of M. macracantha, only one type of tegumental cell, which produces the different kinds of body inclusions, was observed.

\section{REFERENCES}

BAPTISTA-FARIAS, M. F. D., KOHN, A. \& BARTH, O. M., 1995, Ultrastructural aspects of spermatogenesis in Metamicrocotyla macracantha (Alexander, 1954) Koratha, 1955 (Monogenea, Microcotylidae). Mem. Inst. Oswaldo Cruz, 90: 597-604.

BAPTISTA-FARIAS, M. F. D. \& KOHN, A., 1998, Ultrastructural observations of the vitelline cells of Metamicrocotyla macracantha (Monogenea, Microcotylidae). Mem. Inst. Oswaldo Cruz, 93: 543-548.

BARGIELA, J. F., 1987, Los parasitos de la lisa Mugil cephalus L., en Chile: sistemática y aspectos poblacionales (Perciformes: Mugilidae). Gayana, Zool., 51: 3-58.

BRAVO-HOLLIS, M., 1966, Helmintos de peces del Pacífico mexicano. XXV. Descripción de tres monogeneos del Golfo de California. An. Inst. Biol., UNAM, 37: 107-123.
BRAVO-HOLLIS, M., 1982, Helmintos de peces del Pacífico mexicano. XXXVIII. Estudio de monogeneos del suborden Microcotylinea Lebedev, 1972, con la presentación de una subfamilia y una especie nueva. An. Inst. Biol., UNAM, 52: 13-26.

BRENNAN, G. P. \& RAMASAMY, P., 1996, Ultrastructure of the surface structures and electron immunogold labelling of peptide immunoreactivity in the nervous system of Pseudothoracocotyla indica (Polyopisthocotylea: Monogenea). Parasitol. Res., 82: 638-646.

COHEN, S. C., KOHN, A. \& BAPTISTA-FARIAS, M. F. D., 2001, Scanning and transmission electron microscopy of the tegument of Paranaella luquei Kohn, Baptista-Farias \& Cohen, 2000 (Microcotylidae, Monogenea), parasite of a brazilian catfish, Hypostomus regani. Mem. Inst. Oswaldo Cruz, 96: 555-560.

COLLINS, M. R., 1985, Ectoparasites of striped mullet, Mugil cephalus (L.) in brackish and freshwater habitats. Dissert. Abst., 46: 1042.

CONROY, G., CONROY, D. A. \& RODRÍGUEZ, A., 1985, A note on the occurrence of "coiled" Metamicrocotyla macracantha on the gills of silver mullet (Mugil curema) from Chichiriviche, Venezuela. Bul. Eur. Ass. Fish Pathol., 5: 66.

CONROY, G., CONROY, D. A. \& RODRÍGUEZ, A., 1986, A report on Metamicrocotyla macracantha (Monogenea, Monopisthocotylea, Microcotylidae) as a gill parasite of the silver mullet (Mugil curema Valenciennes, 1836) in Venezuela. Riv. Ital. Pisc. Ittiopatol., 21: 118-120.

GARCIA, J. R. \& WILLIAMS, E. H., 1985, Temporal dynamics of metazoan parasite infection in the white mullet, Mugil curema Valenciennes from Joyuda Lagoon, Puerto Rico. Caribbean J. Scienc., 21: 39-53.

HALTON, D. W., 1979, The surface topography of a monogenean, Diclidophora merlangi, revealed by scanning electron microscopy. Z. Parasitenkde., 61: 1-12.

HALTON, D. W., 1982, Morphology and ultrastructure of parasitic helminths. In: D. F. Mettrick \& S. S. Desser (eds.), Parasites: their world and ours. Elsevier Biomedical Press, Holland.

HARGIS, W. J. Jr., 1956, Monogenetic trematodes of Gulf of Mexico fishes. Part X. The family Microcotylidae Taschenberg, 1879. Trans. Amer. Microsc. Soc., 75: 436-453.

JUAREZ-ARROYO, J. \& SALGADO-MALDONADO, G., 1989, Helmintos de la lisa Mugil cephalus Lin. en Topolobampo Sinaloa, México. An. Inst. Biol., UNAM, 60: 279-298.

JUSTINE, J. L., 1992, Ultrastructure of spermiogenesis, spermatozoa and the tegument in Atriaster sp. (Plathyhelminthes, Monogenea, Polyopisthocotylea, Microcotylidae). Zool. Scripta, 21: 231-238.

JUSTINE, J. L. \& BONAMI, J. R., 1993, Virus-like particles in a monogenean (Plathyhelminthes) parasitic in a marine fish. Int. J. Parasitol., 23: 69-75.

KNOFF, M., LUQUE, J. L. \& AMATO, J. F. R., 1997, Community ecology of the metazoan parasites of frey mullets Mugil platannus (Osteichthyes: Mugilidae) from the littoral of the State of Rio de Janeiro. Rev. Brasil. Biol., 57: 441-454. 
KOHN, A., COHEN, S. C. \& BAPTISTA-FARIAS, M. F. D., 1994, A redescription of the morphology of Metamicrocotyla macracantha (Alexander, 1954) Koratha, 1955 (Monogenea, Microcotylidae) from Mugil liza in Brazil. Syst. Parasitol., 27: $127-132$.

KORATHA, K. J., 1955, Studies on the monogenetic trematodes of the Texas coast. II. Description of species from marine fishes of Port Aransas. Pub. Inst. Mar. Sci., Univ. Texas, 4: 251-278

LUFT, J. H., 1961, Improvements in epoxy resin embedding methods. J. Byoph. Citol., 9: 409.

LUQUE, J. L., 1994, Dinámica poblacional de Metamicrocotyla macracantha (Monogenea, Microcotylidae) parasito de Mugil cephalus (Pisces: Mugilidae) en la costa central peruana. Rev. Biol. Trop., 42: 733-735.

LYONS, K. M., 1972, Ultrastructural observations on the epidermis of the polyopisthocotylinean monogeneans Rajonchocotyle emarginata and Plectanocotyle gurnardi. Z. Parasitenkde., 40: 87-100.

LYONS, K. M., 1973, The epidermis and sense organs of the Monogenea and some related groups. Adv. Parasitol., 11: 193-232.

MINCHEW, C. D., 1977, The occurrence of "coiled" Metamicrocotyla maracantha on the gills of the mullet, Mugil cephalus. Proc. Helminthol. Soc. Wash., 44: 106.

OLIVA, M. M. \& MUÑOZ, M. A. A., 1985, Microcotyloidea (Platyhelminthes) - Monogenea en peces marinos de la zona de Antofagasta, Chile. Est. Ocean., 4: 1-8.

RAMASAMY, P. \& BHUVANESWARI, R., 1993, The ultrastructure of the tegument and clamp attachment organ of Gotocotyla bivaginalis (Monogenea: Polyopishtocotylea). Int. J. Parasitol., 23: 213-220.

RAMASAMY, P., HANNA, R. E. B. \& THREADGOLD, L. T., 1986, The surface topography and ultrastructure of the tegument and haptor of Pricea multae (Monogenea). Int. J. Parasitol., 16: 581-589.
RAMASAMY, P., HANNA, R. E. B. \& THREADGOLD, L. T., 1987, Scanning and transmission electron studies of the surface of Vallisia indica (Monogenea: Polyopisthocotylea). Int. J. Parasitol., 17: 1187-1195.

RAWSON, M. V. Jr., 1976, Population biology of parasites of striped mullet, Mugil cephalus L. I. Monogenea. J. Fish Biol., 9: 185-194.

SANTOS, C. P. \& LANFREDI, R. M., 2000, Ultrastructure and cytochemistry of the tegument of Atriaster heterodus (Platyhelminthes: Monogenea) from Diplodus argenteus (Val., 1830) (Teleostei: Sparidae) from Brazil. Mem. Inst. Oswaldo Cruz, 95: 899-904.

SKINNER, R. H., 1975, Parasites of striped mullet, Mugil cephalus, from Biscayne Bay, Florida, with descriptions of new genus and three new species of trematodes. Bull. Mar. Sci., 25: 318-345.

SKINNER, R. H., 1978, Some external parasites of Florida fishes. Bull. Mar. Sci., 28: 590-595.

SMYTH, J. \& HALTON, D. W., 1983, The Physiology of Trematodes. Cambridge University Press, Cambridge.

TANTALEÁN, M. V., 1974, Monogeneos de la familia Microcotylidae Taschenberg, 1879 - parasitos de peces del mar peruano con descripción de una especie nueva. Biota, 10: $120-127$.

THREADGOLD, L. T., 1984, Parasitic platyhelminthes. In: J. Bereiter-Hahn, A. G. Matoltsy \& K. S. Richards (eds.), Biology of the tegument. Vol. 1 Invertebrates. Berlin, Heidelberg, Springer-Verlag, pp. 132-211.

YOUNG, P. C., 1970, The species of Monogenoidea recorded from Australian fishes and notes on their zoogeography. An. Inst. Biol., UNAM, 41: 163-176. 